\title{
Impacts of Shale Gas Wastewater Disposal on Water Quality in Western Pennsylvania
}

\author{
Nathaniel R. Warner, ${ }^{* \dagger}$ Cidney A. Christie, Robert B. Jackson, and Avner Vengosh* \\ Division of Earth and Ocean Sciences, Nicholas School of the Environment, Duke University, Durham, North Carolina 27708, United \\ States
}

\section{Supporting Information}

ABSTRACT: The safe disposal of liquid wastes associated with oil and gas production in the United States is a major challenge given their large volumes and typically high levels of contaminants. In Pennsylvania, oil and gas wastewater is sometimes treated at brine treatment facilities and discharged to local streams. This study examined the water quality and isotopic compositions of discharged effluents, surface waters, and stream sediments associated with a treatment facility site in western Pennsylvania. The elevated levels of chloride and bromide, combined with the strontium, radium, oxygen, and hydrogen isotopic compositions of the effluents reflect the composition of Marcellus Shale produced waters. The discharge of the effluent from the treatment facility increased downstream concentrations of chloride and bromide above background levels. Barium and radium were substantially $(>90 \%)$ reduced in the treated effluents compared to concentrations in Marcellus Shale produced waters. Nonetheless, ${ }^{226} \mathrm{Ra}$ levels in stream sediments $(544-8759 \mathrm{~Bq} / \mathrm{kg})$ at the point of discharge were 200 times greater than upstream and background sediments $(22-44 \mathrm{~Bq} / \mathrm{kg})$ and above radioactive waste disposal threshold regulations, posing potential environmental risks of radium bioaccumulation in localized areas of shale gas wastewater disposal.

\section{INTRODUCTION}

The safe disposal of large volumes of liquid waste associated with natural gas and oil production is a major challenge because the waste fluids often contain high levels of salinity, toxic metals, and radioactivity. ${ }^{1-6}$ In the United States, oil and gas wastewater is managed through recycling of the wastewater for shale gas operations, injection into deep disposal wells, treatment in publicly owned treatment works (POTWs), wastewater treatment plants (WWTP), or commercially operated industrial wastewater treatment plants, and spreading on roads for dust suppression and deicing. Many of these disposal options are sometimes associated with environmental risks and are not available or allowed in some areas (e.g., lack of appropriate geology for deep-well injection sites or regulations that do not allow wastewater to be sprayed on roads or lands in most states). Oil and gas wastewater is composed of drilling fluids, hydraulic fracturing flowback fluids, and produced waters. Here we collectively define all of these fluids as residual wastewater.

In Pennsylvania, the overall estimated volume of oil and gas wastewater $\left(3.1 \times 10^{6}\right.$ to $3.8 \times 10^{6}$ cubic meters per year $)$ has increased during recent years, ${ }^{7,8}$ yet an increasing fraction of the wastewater is also reused. ${ }^{7}$ In 2011 , an estimated $70 \%$ of flowback and produced fluids were reused, and current operations aim to reuse more of the wastewater. ${ }^{7}$ However, options for the proper disposal and management of the wastewater that is not recycled are limited, due to the poor water quality of flowback and produced waters. In 2011, 20\% of drilling fluids, $8 \%$ of hydraulic fracturing flowback fluid, and $14 \%$ of produced water (i.e., brine) from unconventional Marcellus Shale wells were treated at centralized waste treatment facilities (treatment facilities) and then discharged to local streams. ${ }^{7}$ The salinity of shale gas waste fluids varies from $5000 \mathrm{mg} / \mathrm{L}$ to $>200000 \mathrm{mg} / \mathrm{L}$. This high-salinity water typically contains concentrated bromide, chloride, metals such as barium and strontium, and naturally occurring radioactive material (NORM) in the form of radium isotopes with activities of 185 to $592 \mathrm{~Bq} / \mathrm{L} .^{5}$ The elevated salinity and radioactivity in both flowback and produced waters reflect primarily the naturally occurring hypersaline brines that are associated with the formations targeted for natural gas production. ${ }^{3,9}$

Pennsylvania has historically managed wastewater from conventional oil and gas wells (i.e., vertical wells drilled into an oil/gas reservoir) by hauling it to industrial brine treatment facilities, which then discharge treated effluent to surface waters. ${ }^{10}$ In 2010 there were 74 oil and gas water pollution control facilities, including both private brine treatment facilities and publicly owned treatment works (POTWs) permitted or awaiting permit approval to accept wastewater

Received: May 14, 2013

Revised: $\quad$ September 9, 2013

Accepted: September 10, 2013 


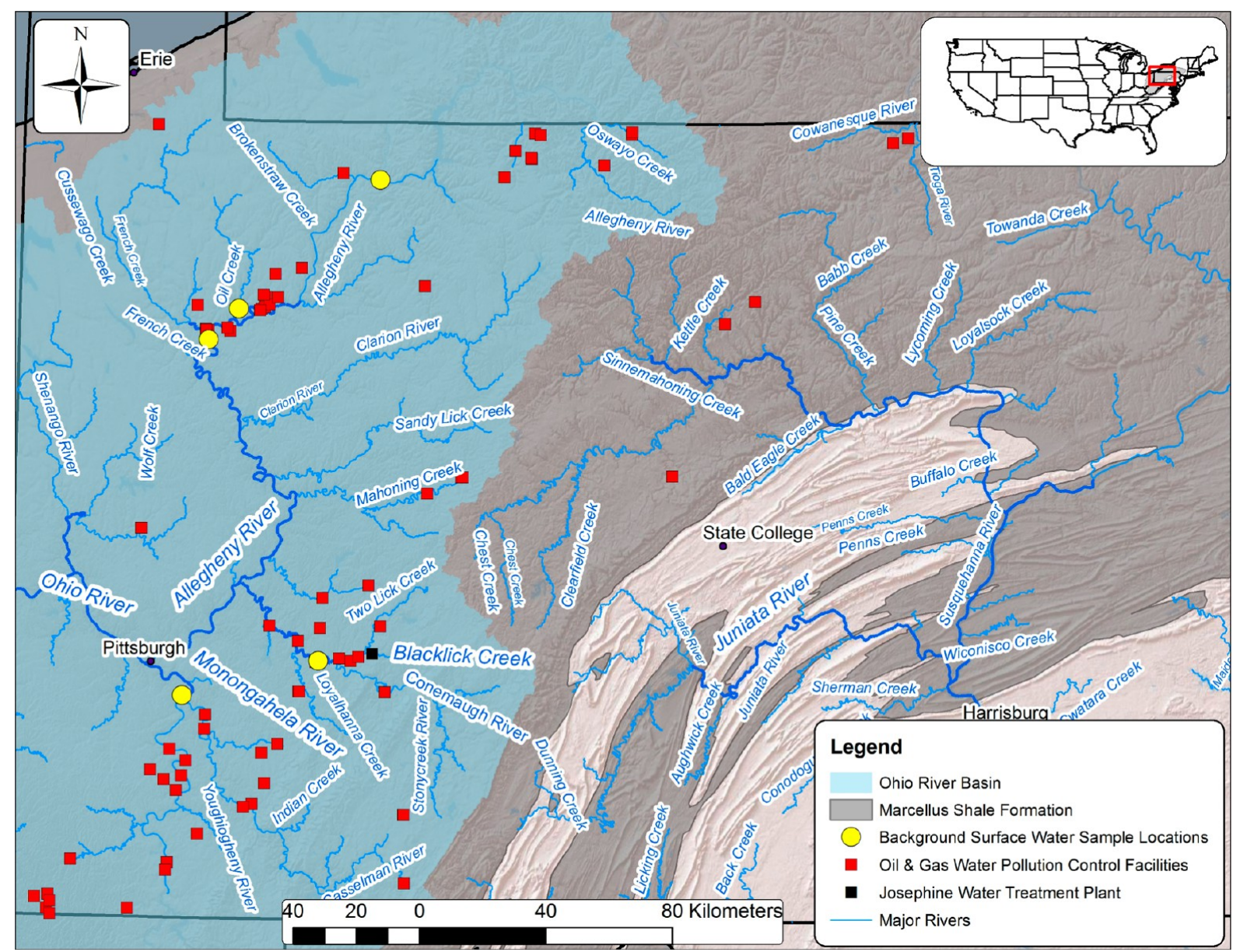

Figure 1. Map of the hydrological system of Pennsylvania and the locations of 74 facilities permitted in 2010 to accept and treat Marcellus Shale produced and flowback waters (red squares), the majority of which are located in the Ohio River Basin (light blue shading). This study focused on the Josephine Brine Treatment Facility (black square), a centralized waste treatment facility in western Pennsylvania where treated wastewater is discharged to Blacklick Creek (See SI Figure S1 for details). Background measurements (yellow circles) were collected in 2011 at locations upstream of any permitted facilities or $>1 \mathrm{~km}$ downstream of permitted facilities.

in Pennsylvania (Figure 1; Supporting Information (SI) text). ${ }^{10}$ Ferrar et al. $(2013)^{11}$ showed that treatment of wastewater by three of these facilities releases elevated concentrations of $\mathrm{Cl}$, $\mathrm{Br}, \mathrm{Sr}$, and $\mathrm{Ba}$ to streams at concentrations above U.S. Environmental Protection Agency (USEPA) maximum contaminant levels, secondary maximum contaminant levels, criterion maximum concentrations, or criterion chronic concentrations. ${ }^{11}$ The disposal of Marcellus wastewater through treatment facilities was also suggested to be linked to an overall increase of $5 \%$ in chloride concentrations at downstream surface water monitoring sites in western Pennsylvania ${ }^{12}$ and likely increased the salt intake at downstream water treatment facilities. 6,13

Veil $(2010)^{10}$ and Ferrar et al. $(2013)^{11}$ described in detail the treatment process of a brine treatment facility in western Pennsylvania, the Josephine Brine Treatment Facility, that exclusively treats oil and gas wastewater. Briefly, at the treatment facility the oil residual is skimmed off of the surface and $\mathrm{Na}_{2} \mathrm{SO}_{4}$ is added to remove salts and metals as a solid precipitate. The residual solid is then hauled to residual waste landfills. ${ }^{11}$ Treated wastewater from the facility was released at a rate of $\sim 0.585$ million liters per day [MLd] (http://www.ahs. dep.state.pa.us/NRS/) to a stream with an average flow of 756 MLd. $^{14}$ During 2010 and 2011, a large portion (>50\%) of wastewater treated in this facility was from the unconventional shale gas wells of the Marcellus Formation, but by September 2011 the amount of the Marcellus wastewater was reduced relative to produced water from conventional sources. ${ }^{11}$

In this study we analyzed the effluents that are discharged from the Josephine Brine Treatment Facility as well as streamwater and sediments, both upstream and downstream from the effluent discharge site along Blacklick Creek (Figure 1). We attempted to quantify the short- and long-term environmental impacts of shale gas wastewater disposal on surface water quality and stream sediments. We hypothesize that (1) the distinctive geochemical and isotopic fingerprints of the wastewater effluent would enable us to distinguish the contribution of unconventional Marcellus wastewater from conventional wastewaters, in spite of the treatment process; (2) mass-balance calculations could quantify the relative contribution of salts in the effluent to the receiving stream; and (3) stream sediment geochemistry would retain a record of the long-term impact of treated wastewater discharge in the local environment.

\section{MATERIALS AND METHODS}

We analyzed the concentrations of major constituents $(\mathrm{Cl}, \mathrm{Br}$, $\left.\mathrm{SO}_{4}, \mathrm{Ca}, \mathrm{Na}, \mathrm{Mg}, \mathrm{Ba}, \mathrm{Sr}\right)$, alkalinity, and isotopic ratios $\left(\delta^{18} \mathrm{O}\right.$, $\delta^{2} \mathrm{H},{ }^{87} \mathrm{Sr} /{ }^{86} \mathrm{Sr}$, and ${ }^{228} \mathrm{Ra} /{ }^{226} \mathrm{Ra}$ ) in effluents from the Josephine Brine Treatment Facility and in streamwater and 
Environmental Science \& Technology

Article

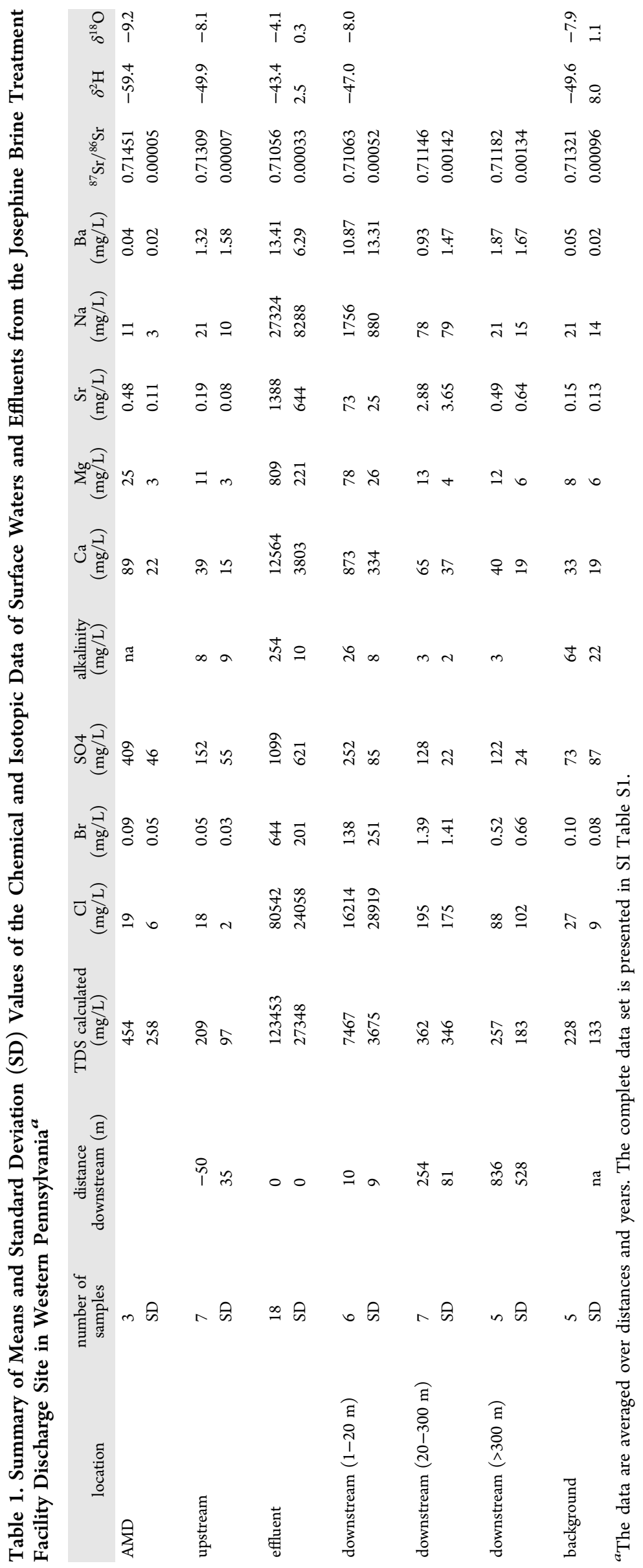

C

dx.doi.org/10.1021/es402165b | Environ. Sci. Technol. XXXX, XXX, XXX-XXX 
sediments upstream and at different distances downstream of the discharge site along Blacklick Creek (SI Figure S1). Wastewater data were compared to background concentrations collected upstream of the facility, from other streams in western $\mathrm{PA}$, and from published values for produced water and flowback from the Marcellus and other Appalachian Basin brines. ${ }^{2-5}$

Samples from the treatment facility site were collected during five field campaigns across a 2-year period beginning in August 2010 and continuing through November 2012. Eighteen effluent and 32 surface water samples were collected. Grab surface water samples were collected from $200 \mathrm{~m}$ upstream to $1780 \mathrm{~m}$ downstream of the effluent discharge from the treatment facility (SI Figure S1). Seven samples were collected in 2011 from other streams/rivers in western PA, including the Conemaugh, Alleghany, and Monongahela Rivers, in an effort to establish background concentrations and variability (Figure 1). On each sampling date, sample collection began with the downstream locations and proceeded upstream to avoid mobilizing sediments. In 2010, samples were collected across the width of Blacklick Creek near the facility outflow (SI Figure S1). Samples were field filtered (0.45 um) for analysis of cations, anions and strontium isotopes. Raw unfiltered samples were collected for alkalinity titration and oxygen and hydrogen isotopes. Following collection, all samples were stored on ice for transport to Duke University for analysis.

Major anions were determined by ion chromatography on a Dionex IC DX-2100 and major cations by direct current plasma optical emission spectrometry (DCP-OES) at Duke University. Alkalinity was determined in duplicate by titration with $\mathrm{HCl}$ to $\mathrm{pH}$ 4.5. Sr isotopes were prepared by total desiccation of sample aliquot containing approximately $3 \mu \mathrm{g}$ of Sr. The dried sample was then digested in $3 \mathrm{~N}$ ultrapure $\mathrm{HNO}_{3}$ and extracted on Eichrom $\mathrm{Sr}$ resin held in Teflon micro columns. The extracted $\mathrm{Sr}$ was then desiccated a second time and digested in $\mathrm{TaCl}$ solution before it was analyzed by thermal ionization mass spectrometer (TIMS) on a ThermoFisher Triton at Duke University. The average ${ }^{87} \mathrm{Sr} /{ }^{86} \mathrm{Sr}$ of the SRM-987 standard measured at Duke during this study was $0.710266 \pm 0.000005$ (SD). Oxygen and hydrogen isotopes of water were determined by thermochemical elemental analysis/continuous flow isotope ratio mass spectrometry (TCEA-CFIRMS), using a ThermoFinnigan TCEA and Delta+XL mass spectrometer at the Duke Environmental Isotope Laboratory (DEVIL). All measured isotopic values were normalized to Vienna Standard Mean Ocean Water (VSMOW).

A large volume (1-4 L) of treated wastewater was collected immediately before the discharge from the treatment facility entered the stream during two of the sampling campaigns in 2011 (SI Figure S1). The samples were filtered through a plastic column containing manganese-oxide covered acrylic fibers, ${ }^{15}$ which efficiently adsorbed the radium isotopes. The fibers were transported to the Laboratory of Environmental RadioNuclides (LEARN) at Duke University. The fibers were then incubated in a sealed glass cylinder for 3 weeks to allow ingrowth of ${ }^{222} \mathrm{Rn}$ (with a half-life of 3.85 days) and measured for ${ }^{226} \mathrm{Ra}$ using a Radon-in-Air monitor (RAD7, Durridge Inc.). ${ }^{16}$ After determination of ${ }^{226} \mathrm{Ra}$, the fibers were then crushed to achieve a uniform geometry packed and sealed in $90 \mathrm{~mL}$ tin cans. Their ${ }^{228} \mathrm{Ra}$ was measured by a Canberra DSA2000 broad energy germanium (BEGe) gamma detector. ${ }^{17}$

Grab sediment samples were also collected from the upper 5 $\mathrm{cm}$ interval over three separate sampling campaigns (20112012) (SI Figure S1). Approximately $100 \mathrm{~g}$ of sediment were scooped out of the stream with a plastic spatula and placed into $200 \mathrm{~mL}$ plastic sediment containers. Sediments were transferred and weighed in $90 \mathrm{~mL}$ tin cans and then dried in an oven at $50{ }^{\circ} \mathrm{C}$ for $24 \mathrm{~h}$. The dried sediments were crushed to a diameter $<5 \mathrm{~mm}$ using a mortar and pestle, weighed, and sealed in the can with electrical tape to prevent gas escape during incubations. The sealed cans were incubated for at least 3 weeks before each sample was counted on the gamma detector. ${ }^{226} \mathrm{Ra}$ activities were obtained through the $609 \mathrm{keV}$ energy line of its decay product, ${ }^{214} \mathrm{Bi}$, assuming secular equilibrium. ${ }^{228} \mathrm{Ra}$ activities were obtained through the $911 \mathrm{keV}$ energy line. The activities of all nuclides were calibrated using CCRMP UTh ore standard DL-1a measured under similar physical conditions (e.g., can geometry).

Statistical analysis was performed using STATA statistical software. Parameters were not normally distributed and therefore they were analyzed using a nonparametric rank sum analysis (Wilcoxon-Mann-Whitney).

\section{RESULTS AND DISCUSSION}

Characterization and Sources of the Wastewater Effluent. The concentrations of major elements $(\mathrm{Cl}, \mathrm{Br}, \mathrm{Ca}$, $\mathrm{Na}$, and $\mathrm{Sr}$ ) in the treated wastewater effluent varied throughout the two-year sampling period, with levels up to 6,700 times higher than the concentrations measured in the upstream river sites (Table 1 and SI Table S1). For example, chloride concentrations in upstream Blacklick Creek and other upstream background sites were low $(15-21 \mathrm{mg} / \mathrm{L})$ throughout the study 2010-2012, whereas chloride in wastewater effluent concentrations ranged between 55000 and $98000 \mathrm{mg} /$ $\mathrm{L}$ (about 2-5 times the concentration of seawater).

Major element concentrations $(\mathrm{Cl}$ and $\mathrm{Br}$ ) of wastewater effluent were similar to the concentrations reported for produced and flowback waters from the Appalachian Basin (Table 2).$^{2-4,9,18}$ In addition, wastewater effluents had high $\mathrm{Br} /$ $\mathrm{Cl}$ ratios $\left(3-4 \times 10^{3}\right)$, which characterize the Appalachian produced and flowback waters. This reflects the conservative behavior (i.e., not added or removed) of these elements throughout the treatment process. The concentrations of other nonconservative elements (e.g., $\mathrm{Na}, \mathrm{Ca}, \mathrm{Sr}, \mathrm{Ba}$ ) were more varied, which is consistent with previous findings (SI Table S1). ${ }^{11}$ Sulfate was significantly $(p \ll 0.01)$ enriched in the treated effluent relative to Marcellus flowback and produced waters, likely due to the addition of $\mathrm{Na}_{2} \mathrm{SO}_{4}$ during treatment (SI Table S2). In contrast, barium and radium contents in the effluents showed a significant $(p \ll 0.01)$ average reduction of 99\% (Table 2) relative to Marcellus flowback, indicating an effective removal during treatment.

The total activity of radium (i.e., ${ }^{226} \mathrm{Ra}+{ }^{228} \mathrm{Ra}$ ) in wastewater effluent $\left({ }^{226} \mathrm{Ra}=0.11\right.$ to $0.19 \mathrm{~Bq} / \mathrm{L}$ and ${ }^{228} \mathrm{Ra}=0.04$ to 0.13 $\mathrm{Bq} / \mathrm{L}$; SI Table S3) was well below the industrial discharge limit of $2.2 \mathrm{~Bq} / \mathrm{L}(60 \mathrm{pCi} / \mathrm{L}$ in the U.S $)$. The total activities we measured were within the range of the radium values reported in May-June 2011 by the treatment facility to the USEPA $\left({ }^{228} \mathrm{Ra}\right.$ range of zero to $0.74 \mathrm{~Bq} / \mathrm{L}$ and ${ }^{226} \mathrm{Ra}$ range 0.05 to 3.24 $\mathrm{Bq} / \mathrm{L})^{19}$ and similar to values reported by Pennsylvania Department of Environmental Protection for effluent at other brine treatment facilities in western Pennsylvania (http://files. dep.state.pa.us/OilGas / BOGM/BOGMPortalFiles / RadiationProtection/NORM.pdf). The ${ }^{228} \mathrm{Ra} /{ }^{226} \mathrm{Ra}$ ratio of the effluent sample we collected in August 2011 was 0.39, consistent with ratios reported for Marcellus flowback and produced water. ${ }^{5}$ In June 2012 , the ${ }^{228} \mathrm{Ra} /{ }^{226} \mathrm{Ra}$ ratio was 0.69 , 


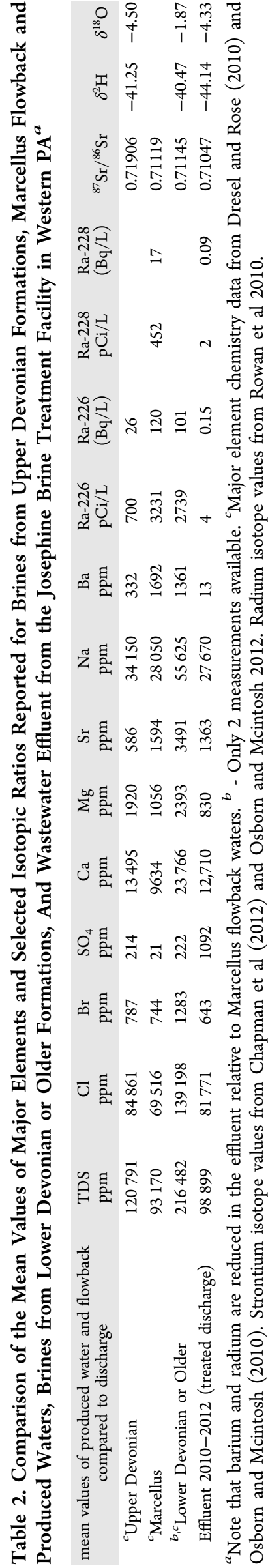

which is closer to ratios reported for wastewaters from conventional oil and gas wells in the Appalachian Basin (0.79 to 1.61 range). ${ }^{5}$ The increase in ${ }^{228} \mathrm{Ra} /{ }^{226} \mathrm{Ra}$ ratio could reflect a change in the relative proportions of the different types of wastes treated at the facility, with a decrease in the percentage of the Marcellus flowback. ${ }^{11}$

The $\delta^{18} \mathrm{O}$ and $\delta^{2} \mathrm{H}$ values of wastewater effluent $\left(\delta^{18} \mathrm{O}=\right.$ $-3.85 \%$ o to $-4.39 \%$; $\delta^{2} \mathrm{H}=-40.8 \%$ o to $-45.6 \%$ ) overlapped with the values reported for produced water from western PA wells ${ }^{2,4}$ and were higher than background surface water in western PA $\left(\delta^{18} \mathrm{O}=-6.4 \%\right.$ o to $-9.4 \%$; $\delta^{2} \mathrm{H}=-41.7 \%$ o to $-60.8 \%$ ) (SI Figure S2). The wastewater effluent also had a different $\delta^{2} \mathrm{H}-\delta^{18} \mathrm{O}$ slope relative to the local meteoric water line (LMWL). ${ }^{20} \mathrm{The}{ }^{87} \mathrm{Sr} /{ }^{86} \mathrm{Sr}$ ratios of the wastewater effluents ranged from 0.7101 to 0.7111 and are consistent with the isotopic ratios of the Marcellus brines (Figure 2)., ${ }^{9,18}$ These

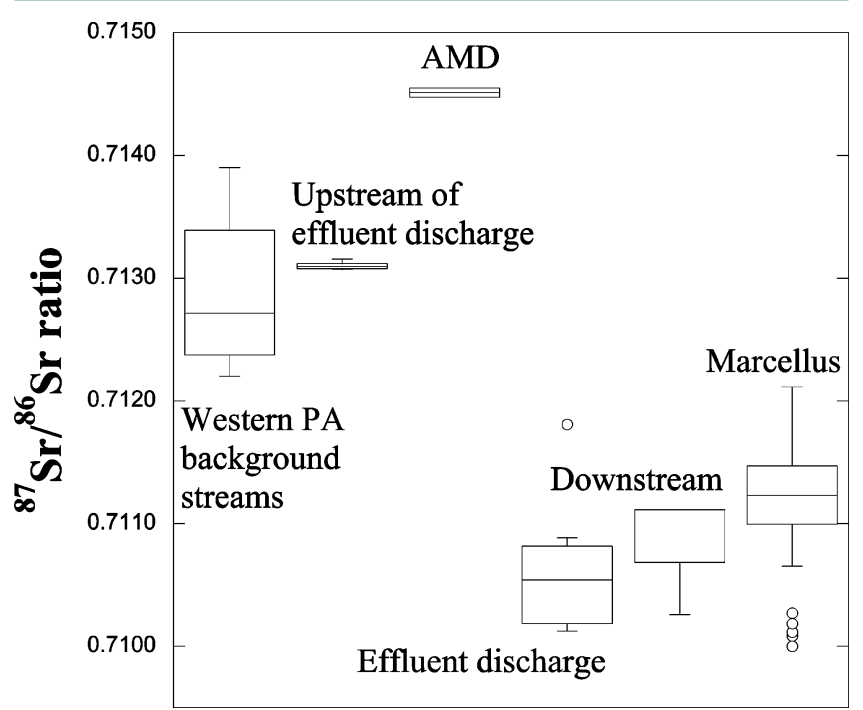

Figure 2. Variations of ${ }^{87} \mathrm{Sr} /{ }^{86} \mathrm{Sr}$ isotopic ratios in flowback fluids and produced waters from the Marcellus Shale, acid mine drainage (AMD), treatment facility discharge, surface waters upstream of the treatment facility, river waters directly downstream of the facility, and background surface waters in western PA. The ranges in ${ }^{87} \mathrm{Sr} /{ }^{86} \mathrm{Sr}$ (0.7101 to 0.7108 ) of the discharge effluent and downstream river are consistent with reported values for Marcellus flowback waters ${ }^{9,18}$ and distinct from AMD (0.7145), background river values upstream of the facility (0.7131), and the range of background samples of surface water in western PA (0.7122-0.7145).

values are distinct from the ${ }^{87} \mathrm{Sr} /{ }^{86} \mathrm{Sr}$ ratios of acid mine drainage (AMD; 0.7145-0.7146), surface water collected upstream of the facility $(0.7130-0.7131)$, and background surface water (upstream from any discharge site) samples collected in western PA (0.7122-0.7145; Figure 2). We observed a slight increase in ${ }^{87} \mathrm{Sr} /{ }^{86} \mathrm{Sr}$ in the effluent with time, which is consistent with the changes we observed in the ${ }^{228} \mathrm{Ra} /{ }^{226} \mathrm{Ra}$ ratios. One possible explanation for this change is a decrease in the relative volume of Marcellus wastewater treated at the investigated brine treatment facility during 2012. Overall, the use of multiple geochemical and isotopic tracers $(\mathrm{Br} / \mathrm{Cl}$, ${ }^{87} \mathrm{Sr} /{ }^{86} \mathrm{Sr},{ }^{228} \mathrm{Ra} /{ }^{226} \mathrm{Ra}, \delta^{18} \mathrm{O}$, and $\left.\delta^{2} \mathrm{H}\right)$ confirms that a large fraction of the discharged effluent from the investigated site originated from wastewater associated with shale gas development, at least during 2010-2011.

Salt Flux. We calculated the total flux of salts discharged by the facility to the stream by multiplying the mean 
concentrations of dissolved salts in the effluent by the total discharged volume of effluent. We assume the average concentration of salts in the effluents reported in this study and the reported discharge flux $(0.585 \mathrm{MLd})$ reflect the yearly effluent flux from the Josephine brine treatment facility (http:// www.ahs.dep.state.pa.us/NRS/, Josephine facility; ID = PA0095273). Our calculations show that the total annual chloride and bromide fluxes to the stream were $17.4 \times 10^{3}$ and $136.5 \mathrm{t} /$ year, respectively. For comparison, the annual chloride flux of the upstream river was only $4.8 \times 10^{3}$ metric tons/year. Therefore averaged over the year, the discharged effluent from the treatment facility contributes about $78 \%$ of the total downstream chloride flux from only $0.1 \%$ of the average flow volume (SI Table S4).

Maloney and Yoxhiemer $(2012)^{7}$ reported a total of $390 \mathrm{ML}$ of Marcellus wastewater disposed to wastewater treatment plants during 2011. Lutz et al. (2013) ${ }^{8}$ reported larger volumes disposed at treatment facilities, $1752.8 \mathrm{ML}$ in 2010 and $\sim 1200$ ML in 2011. Wilson and VanBriesen $(2012)^{6}$ estimated Marcellus wastewater disposal to treatment plants increased both TDS and $\mathrm{Br}$ loading to downstream drinking water sources. Assuming that the studied site represents the Marcellus waste stream approximately, we estimate that in 2010-2011 the overall chloride flux (flux $=$ discharge volume $\mathrm{x}$ concentration) to streams directly from Marcellus wastewater disposal was between $32 \times 10^{3}$ and $143 \times 10^{3}$ metric tons/year. Similarly, bromide fluxes were between 250 and 1,130 t/year. For comparison, these estimates would theoretically represent between $4.5 \%$ and $17 \%$ of the total annual chloride flux $(684 \times$ $10^{3}$ metric tons/year) in an Ohio River with "background" chloride concentration of $24 \mathrm{mg} / \mathrm{L}$ and an average flow rate of $28.5 \times 10^{6} \mathrm{ML} /$ year measured near Pittsburgh (SI Table S5). The relative contribution of bromide to the Ohio River from Marcellus wastewater disposal was larger, between $19.5 \%$ and $89 \%$. The Ohio River was selected as an example because the vast majority of disposal facilities are located within its watershed (Figure 1).

Effects on Surface Water Quality. Surface water samples collected downstream of the wastewater effluent discharge in Blacklick Creek showed a significant dilution relative to the effluent for concentrations of all major elements (Table 1 and SI Tables S1 and S6). To evaluate the impact of the wastewater discharge, we calculated the enrichment factors (EFs) for each element, using the concentrations measured at downstream sites divided by the upstream concentrations. For a conservative element like chloride, the EF was $>6000$ at the point of discharge. The EF substantially decreased downstream as the effluent mixed with the streamwater. However, an EF value of 16 for chloride was recorded $1.78 \mathrm{~km}$ downstream of the effluent discharge (Figure 3a). Likewise, bromide concentrations were very low in upstream samples $(0.03-0.1 \mathrm{mg} / \mathrm{L})$ and were enriched by $6000-12000$ in the wastewater effluent. The downstream bromide EF values at distances of 300, 600, and $1780 \mathrm{~m}$ were 186,33 , and 37 , respectively (Figure $3 \mathrm{~b}$ ). Our data show that in spite of a major dilution of the bromide-rich wastewater effluent, downstream river water had a significant bromide enrichment of almost 40 fold even at a distance of 1.78 $\mathrm{km}$ from the discharge site (although this conclusion is based on a single sampling event during low $\sim 5 \mathrm{~m}^{3} / \mathrm{s}$ streamflow). Overall, downstream concentrations were significantly higher than upstream concentrations $(p<0.01$, Wilcoxon-MannWhitney test; SI Table S6).
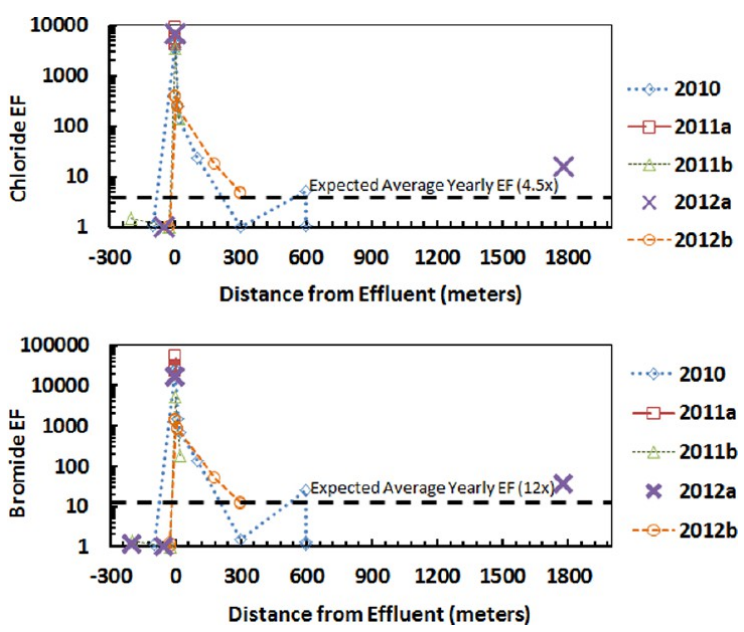

Figure 3. $a$ and b. Surface water enrichment factors (EFs) in logarithmic scale of $\mathrm{Cl}$ and $\mathrm{Br}$ plotted versus distance from the discharge site of the investigated treatment facility in western PA. EFs were calculated relative to upstream surface water concentrations for each of five sampling events. Samples plotted upstream (values on the $X$-axis between -300 and -25 ) include both surface water samples collected directly upstream of the discharge site as well as acid mine drainage (AMD) contribution to the stream near the facility. The data show variability in concentrations during the same sampling event at the same distance downstream due to differential mixing of the effluents and river waters perpendicular to streamflow. Values of the calculated average yearly EFs within the stream are marked in dashed lines.

The EF data calculated above represent single sampling events. A more robust estimate of yearly average EF in the stream can be determined by using the average concentrations of bromide upstream of the facility $(0.045 \mathrm{mg} / \mathrm{L})$ and in the effluent $(643 \mathrm{mg} / \mathrm{L})$, combined with the average streamflow (756 MLd) and the treatment facility's reported discharge rate (0.585 MLd for 2012). Our calculations reveal an average yearly EF of 4.8 and 12.3 for $\mathrm{Cl}$ and $\mathrm{Br}$, respectively (Figure 3a and $b$ ). It is important to note that this is an average EF of the total salt flux, and seasonal fluctuations in streamflow can substantially alter the EF on any given day. However, the overall bromide enrichment in river water could be critical to downstream municipal water treatment plants, given the potential formation of carcinogenic trihalomethane compounds in chlorinated drinking water upon chlorination of water with even slightly enriched bromide. ${ }^{6,19}$

More reactive constituents such as $\mathrm{Mg}, \mathrm{Ca}, \mathrm{Ba}, \mathrm{Sr}$, and $\mathrm{Na}$ (SI Figures S3a-e) showed lower EFs in the wastewater effluent discharge (200 to 20000 ), which likely reflects the partial removal of these metals during the treatment process. Much lower EFs (1-3) were also recorded in the downstream surface water sites, inferring an additional uptake of these elements in the river sediments and potentially limited impact on the streamwater quality. The ${ }^{87} \mathrm{Sr} /{ }^{86} \mathrm{Sr}$ measured in downstream river waters (0.7102-0.7130; Figure 2) were in many cases identical to the wastewater effluents and significantly lower relative to the upstream values (0.713070.71309 ). The investigated stream was also influenced by AMD discharge with ${ }^{87} \mathrm{Sr} /{ }^{86} \mathrm{Sr}$ of $0.71455-0.71447$, higher than values measured upstream $(\sim 0.713)$ and other reported values of AMD in western Pennsylvania $\left(\sim 0.712^{21}\right.$ and $0.712-0.718$ ${ }^{22}$ ). Overall, our data show that in spite of the dilution of the wastewater effluent in the river system, different elements, in 
particular chloride and bromide, were elevated in downstream water compared to the upstream river.

Effects on Radium in Stream Sediments. The ${ }^{226} \mathrm{Ra}$ activities in both the background river sediments and the sediments in Blacklick Creek directly upstream of the discharge were low (22.2 Bq/kg to $44.4 \mathrm{~Bq} / \mathrm{kg}$; Figure 4; SI Table S3)

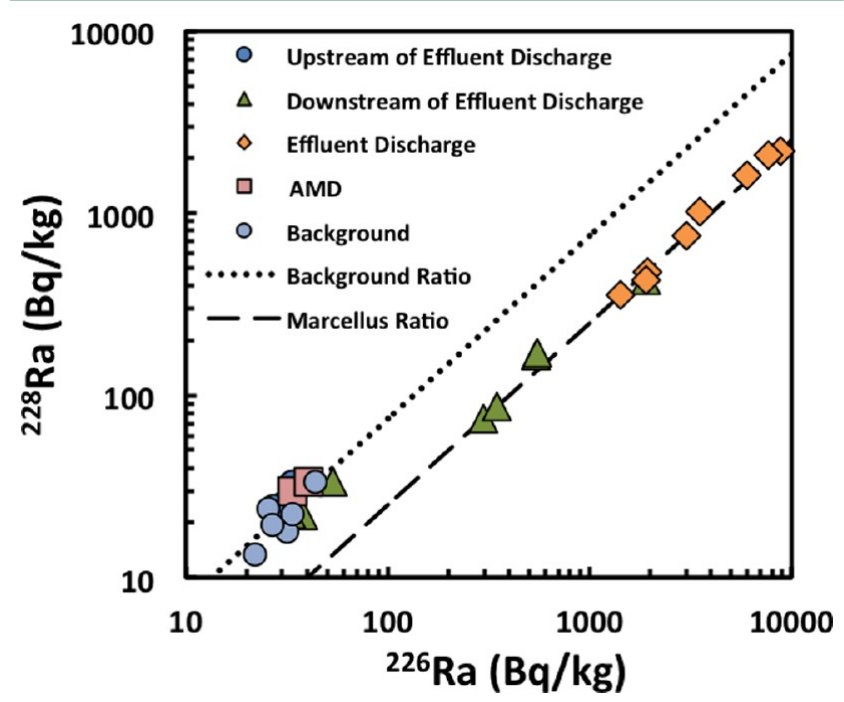

Figure 4. Activities of ${ }^{228} \mathrm{Ra}$ versus ${ }^{226} \mathrm{Ra}(\mathrm{Bq} / \mathrm{kg})$ in river sediments collected upstream, adjacent, and downstream of the wastewater discharge site. Note that the maximum of both ${ }^{226} \mathrm{Ra}(8732 \mathrm{~Bq} / \mathrm{kg})$ and ${ }^{228} \mathrm{Ra}(2072 \mathrm{~Bq} / \mathrm{kg})$ activities were from samples collected in river sediments adjacent $(<10 \mathrm{~m})$ to the effluent discharge point and are 200 times greater than any sediment sample collected upstream of the facility or any background sediment samples collected from other western PA surface waters. The ${ }^{228} \mathrm{Ra} /{ }^{226} \mathrm{Ra}$ ratio $(0.22-0.27)$ in the sediments at the discharge point is consistent with Marcellus brine and flowback waters (dashed line; ratio $=0.25$ ). This isotopic signature measured in sediments from the discharge site is distinct from any background river sediment samples and acid mine drainage (AMD) with higher ${ }^{228} \mathrm{Ra} /{ }^{226} \mathrm{Ra}$ ratios $(0.56-0.97$; dotted line ratio of 1$)$.

with ${ }^{228} \mathrm{Ra} /{ }^{226} \mathrm{Ra}$ ratios of $0.56-0.97$. These $\mathrm{Ra}$ activities are consistent with background $\mathrm{Ra}$ activities reported in soils of western New York (mean ${ }^{226} \mathrm{Ra}=33.3 \mathrm{~Bq} / \mathrm{kg}$ and ${ }^{228} \mathrm{Ra}=51.8$ $\mathrm{Bq} / \mathrm{kg}^{23}$ ) and background river sediments $\left(4-126 \mathrm{~Bq} / \mathrm{kg}^{24}\right.$ and $44 \mathrm{~Bq} / \mathrm{kg}$ to $91 \mathrm{~Bq} / \mathrm{kg}$ for suspended matter $\left.{ }^{25}\right)$. In contrast, immediately adjacent to the treatment facility discharge site we recorded much higher maximum activities of both ${ }^{226} \mathrm{Ra}(8732$ $\mathrm{Bq} / \mathrm{kg}$ ) and ${ }^{228} \mathrm{Ra}(2072 \mathrm{~Bq} / \mathrm{kg}$ ) in the sediments (SI Table S3; Figure 4). These $\mathrm{Ra}$ activities were 200 times greater than any background sediment samples collected either upstream of the facility or from other western PA rivers (SI Table S3) for sediment samples of similar grain size (SI Table S7). The mean values of all sediment samples collected from within $10 \mathrm{~m}$ of the discharge site $(n=7)$ were $4255 \mathrm{~Bq} / \mathrm{kg}$ and $1110 \mathrm{~Bq} / \mathrm{kg}$ for ${ }^{226} \mathrm{Ra}$ and ${ }^{228} \mathrm{Ra}$, respectively. These radioactivity levels are typical values for technologically enhanced naturally occurring radioactive material (TENORM), and are above management regulations in the U.S. that range from 185 to $1850 \mathrm{~Bq} / \mathrm{kg}$ (5 to $50 \mathrm{pCi} /$ gram; http://www.tenorm.com/regs2.htm). For example, in Michigan a radiation threshold that would require transportation of solid waste to a licensed radioactive waste disposal facility is $1850 \mathrm{~Bq} / \mathrm{kg}$ or $50 \mathrm{pCi} / \mathrm{g} .{ }^{26}$ Consequently, our data show that in spite of a significant reduction in $\mathrm{Ra}$ activities in the discharge water, the treated effluent has a significant impact on the sediments in Blacklick Creek because Ra has apparently adsorbed and accumulated on the sediments locally at the discharge site (SI Tables S3 and S6).

The ${ }^{228} \mathrm{Ra} /{ }^{226} \mathrm{Ra}$ ratio measured in the river sediments at the discharge site $(0.22-0.27)$ is consistent with ratios reported for Marcellus flowback and produced water ${ }^{5}$ and lower than the ratios recorded in all other background sediment samples we collected throughout western PA (0.56-0.97; SI Table S3; Figure 4). The relatively low ${ }^{228} \mathrm{Ra} /{ }^{226} \mathrm{Ra}$ ratio in the sediments near the discharge site likely represents the influence of recent discharge of Marcellus flowback and produced waters. Because the decay of ${ }^{228} \mathrm{Ra}$ (5.76 years half-life) is faster than ${ }^{226} \mathrm{Ra}$ (1600 year half-life), discharge of fluids with ${ }^{228} \mathrm{Ra} /{ }^{226} \mathrm{Ra}$ of $\sim 0.9$ would also result in ${ }^{228} \mathrm{Ra} /{ }^{226} \mathrm{Ra}$ ratios measured in the sediments of $\sim 0.22-0.27$ after 10 to 12 years of decay. Given the longer history (i.e., several decades) of conventional oil and gas wastewater disposal to streams in western PA, past disposal of conventional oil and gas waste would likely result in much lower ${ }^{228} \mathrm{Ra} /{ }^{226} \mathrm{Ra}$ ratios. The accumulation of $\mathrm{Ra}$ in the river sediments therefore appears to be primarily related to adsorption from recent wastewater discharge dominated by unconventional shale gas wastes.

A large portion $(>50 \%)$ of the brine treated by the facility in 2010 and 2011 was Marcellus Formation flowback, ${ }^{11}$ with an average reported activity of $185 \mathrm{~Bq} / \mathrm{L} .{ }^{5}$ Assuming that the mean value of combined ${ }^{226} \mathrm{Ra}$ and ${ }^{228} \mathrm{Ra}$ reported for Marcellus flowback and produced waters by Rowan et al. $(2011)^{5}$ represented the brine accepted and treated at the facility, the ${ }^{226} \mathrm{Ra}+{ }^{228} \mathrm{Ra}$ activities in the treated effluents indicate a 1000 fold reduction in radium (Table 2). The wastewater treatment through the facility involves $\mathrm{Na}_{2} \mathrm{SO}_{4}$ addition that likely promotes radium coprecipitation with solid barium sulfate within the facility. The accumulation of $\mathrm{Ra}$ as this solid sludge that is then hauled to residual landfills represents a TENORM, common in oil and gas industry wastes such as scale and sludge, that could pose significant exposure risks if not properly managed. ${ }^{27,28}$

Based on the measurements of drastically reduced radium in the effluent, we calculated the total radium likely removed from the wastewater by the treatment facility. Assuming one-half of the 0.585 MLd treated in the facility in 2010 was Marcellus flowback or produced water with an estimated Ra activity of $180 \mathrm{~Bq} / \mathrm{L}$, and that for every liter of liquid wastewater, $100 \mathrm{~g}$ $(10 \%)$ of solid/sludge precipitated out of the liquid during the wastewater treatment process, the solid product would contain roughly $900 \mathrm{~Bq} / \mathrm{kg}$ of radium. This estimated level of radiation in the waste treatment solids/sludge would then exceed the U.S. regulations for ${ }^{226} \mathrm{Ra}$ disposal to soil of 5-15 pCi/g (185$555 \mathrm{~Bq} / \mathrm{kg}$ ) (http://www.tenorm.com/regs2.htm). These values could also exceed many of the typical municipal landfill limits for TENORM in the U.S., which range from 5 to $50 \mathrm{pCi} /$ gram (185-1850 Bq/kg; http://www.tenorm.com/regs2.htm). It should be noted that our calculations for the possible $\mathrm{Ra}$ content in the treatment residual solids assume that only wastewaters from shale gas wells contained Ra. Yet, produced waters from conventional oil and gas wells in Pennsylvania and New York also have elevated levels of radioactivity, similar to those from the Marcellus Formation. ${ }^{5}$

Although the treatment facility substantially reduces the $\mathrm{Ba}$ and $\mathrm{Ra}$ in the treated discharge, there is also still a flux of $\mathrm{Ra}$ to the stream that we estimate to be $39 \times 10^{6} \mathrm{~Bq} /$ year (i.e., 0.585 $\mathrm{MLd} \times 0.185 \mathrm{~Bq} / \mathrm{L} \times 365$ days). However, our data show that the Ra likely does not remain in the liquid phase and flow 
downstream; instead, most of the Ra appears to be adsorbed and retained in river sediments near the discharge site. Because $\mathrm{Ra}$ adsorption increases with decreasing salinity (i.e., the dilution of dissolved salts), ${ }^{29-31}$ the mixing of the saline wastewater effluents and upstream low-saline water apparently enhances $\mathrm{Ra}$ adsorption onto the sediments.

The sediments we analyzed near the treatment facility could be remobilized and transported downstream during storm events, but the major impact of $\mathrm{Ra}$ appears to be localized ( $<200 \mathrm{~m}$ downstream; Table 1; SI Table S1), creating a zone of concentrated $\mathrm{Ra}$ in the river bottom sediments. The accumulation of $\mathrm{Ra}$ in sediments locally could pose significant ecological risks to benthic organisms in particular. Bioaccumulation of $\mathrm{Ra}$ is known to occur in freshwater fish, invertebrates, mollusks, and shells with reported concentration factors (CF) of 100-1000. ${ }^{24,32-34}$ Although the most likely bioaccumulation pathway is through the benthic environment, radium also accumulates in freshwater plants with an apparent CF of 432 in algae $^{35}$ and up to 1000 in phytoplankton in rivers ${ }^{24}$ although the majority of these studies examined dissolved radium values. Further investigations should focus on the possible bioaccumulation of radium in areas of wastewater discharge, spills, or other areas where shale gas wastewater is released to the environment.

In summary, the discharge of wastewater effluent to surface water has a discernible impact on the water quality of the stream. The chloride concentrations $1.7 \mathrm{~km}$ downstream of the treatment facility were 2-10 times higher than any chloride concentrations recorded in any background western PA streams that we examined. The average yearly EF of chloride in the stream was calculated to be 4.6 times background concentrations. These data support recent studies that suggest treatment facilities have an impact on concentrations of chloride throughout western PA. ${ }^{6,12,13}$ These results also demonstrate that even a 500-3000 dilution of the wastewater effluent is not sufficient to reduce bromide content to background levels; thus, discharge of wastewater could potentially increases the concentrations of $\mathrm{Br}$ in downstream drinking-water treatment facilities. ${ }^{6}$

Our data show that the geochemical signature of Marcellus wastewater is apparent, even after treatment, in the effluents from the treatment facility and in the downstream water and sediments. The majority of elemental chemistry and isotopic ratios $\left(\delta^{18} \mathrm{O}, \delta{ }^{2} \mathrm{H},{ }^{87} \mathrm{Sr} /{ }^{86} \mathrm{Sr},{ }^{228} \mathrm{Ra} /{ }^{226} \mathrm{Ra}\right)$ in treated wastewater effluents during 2010 and 2011 were similar to the compositions of flowback and produced waters from the Marcellus shale gas operations. Therefore we conclude that despite treatment, the isotopic ratios in the effluent can still be used as tracers for delineating the sources of oil and gas wastewaters.

Overall we show that treatment in Josephine Brine Treatment Facility reduces the concentrations of some elements before releasing them into the stream, but wastewater discharge nevertheless reduces the quality of downstream surface water and sediments. Discharge of conventional and unconventional shale gas wastewaters has generated a flux of contaminants to surface water that created an extended mixing zone with high concentrations above background levels. These fluxes include elevated bromide concentrations in downstream river water and the generation of TENORM contamination in stream sediments at the discharge site. Given the long decay rate of ${ }^{226} \mathrm{Ra}$ (i.e., half-life of 1600 years), $\mathrm{Ra}$ and its decayproduct nuclides will remain in the environment generating radiation over a long time period. Future studies should explore Ra bioaccumulation and other ecological effects at wastewater discharge sites. Moreover, advanced treatment technologies should be applied to prevent discharge of contaminants, including $\mathrm{Ra}$ and $\mathrm{Br}$, to the environment in areas of shale gas development and hydraulic fracturing. Future studies should also examine the disposal options for residue solids generated during the treatment process and their suitability for disposal in municipal landfills (Subtitle C and D), which may not be designed for the expected high levels of radioactivity and could pose potential groundwater contamination problems in the future.

\section{ASSOCIATED CONTENT}

\section{Supporting Information}

A Supporting Information (SI) section contains additional text describing methods in greater detail and background information on waste disposal methods. Additional tables and figures of chemical and isotopic are also included. This material is available free of charge via the Internet at http://pubs.acs.org.

\section{AUTHOR INFORMATION}

\section{Corresponding Authors}

*(A.V.) Phone: 919-681-8050; fax: 919-684-5833; e-mail: vengosh@duke.edu.

* (N.W.) Phone: 603-646-9961; e-mail: Nathaniel.r.warner@ dartmouth.edu.

Present Address

${ }^{\dagger}$ Department of Earth Sciences, Dartmouth College, Hanover, NH 03755, United States

\section{Notes}

The authors declare no competing financial interest.

\section{ACKNOWLEDGMENTS}

We gratefully acknowledge funding from Fred and Alice Stanback and Park Foundation to the Nicholas School of the Environment. We thank William Chameides, the Dean of the Nicholas School of Environment for supporting this research. Gary Dwyer provided guidance on sample preparation and analysis. Kyle Ferrar and Drew Michanowicz of the Center for Healthy Environments and Communities and Samantha Malone of Fractracker.org facilitated field-sampling activities for multiple sampling events. Jon Karr and the Duke Environmental Isotope Laboratory (DEVIL) performed analyses of $\delta^{18} \mathrm{O}$, and $\delta^{2} \mathrm{H}$ of surface water samples. We thank the editor, and three anonymous reviewers for improving the quality of this manuscript.

\section{REFERENCES}

(1) Kargbo, D. M.; Wilhelm, R. G.; Campbell, D. J. Natural gas plays in the Marcellus Shale: Challenges and potential opportunities. Environ. Sci. Technol. 2010, 44 (15), 5679-5684.

(2) Dresel, P.,and Rose, A. Chemistry and Origin of Oil and Gas Well Brines in Western Pennsylvania: Pennsylvania Geological Survey; Pennsylvania Department of Conservation and Natural Resources, 2010.

(3) Haluszczak, L. O.; Rose, A. W.; Kump, L. R. Geochemical evaluation of flowback brine from Marcellus gas wells in Pennsylvania, USA. Appl. Geochem. 2013, 28, 55-61.

(4) Osborn, S. G.; McIntosh, J. C. Chemical and isotopic tracers of the contribution of microbial gas in Devonian organic-rich shales and reservoir sandstones, northern Appalachian Basin. Appl. Geochem. 2010, 25 (3), 456-471. 
(5) Rowan, E., Engle, M., Kirby, C., and Kraemer, T. Radium content of oil- and gas-field produced waters in the northern Appalachian Basin (USA)-summary and Discussion of Data: U.S. Geological Survey Scientific Investigations Report 2011-5135; U.S. Geological Survey, 2011.

(6) Wilson, J. M.; VanBriesen, J. M. Oil and gas produced water management and surface drinking water sources in Pennsylvania. Environ. Pract. 2012, 14, 288-300.

(7) Maloney, K.; Yoxtheimer, D. Production and disposal of waste materials from gas and oil extraction from the Marcellus Shale play in Pennsylvania. Environ. Pract. 2012, 14, 278-287.

(8) Lutz, B. D.; Lewis, A. N.; Doyle, M. W. Generation, transport, and disposal of wastewater associated with Marcellus Shale gas development. Water Resour Res 2013, 49 (2), 647-656.

(9) Warner, N. R.; Jackson, R. B.; Darrah, T. H.; Osborn, S. G.; Down, A.; Zhao, K.; White, A.; Vengosh, A. Geochemical evidence for possible natural migration of Marcellus Formation brine to shallow aquifers in Pennsylvania. Proc. Natl. Acad. Sci. U. S. A. 2012, 109 (30), 11961-11966.

(10) Veil, J. Water Management Technologies Used by Marcellus Shale Gas Producers; prepared for U.S. Department of Energy Office of Fossil Fuel Energy, National Energy Technology Laboratory, 2010.

(11) Ferrar, K. J.; Michanowicz, D. R.; Christen, C. L.; Mulcahy, N.; Malone, S. L.; Sharma, R. K. Assessments of effluent contaminants from three wastewater treatment plants discharging Marcellus Shale wastewater to surface waters in Pennsylvania. Environ. Sci. Technol. 2013, 47 (7), 3472-3481.

(12) Olmstead, S. M.; Muehlenbachs, L. A.; Shih, J.-S.; Chu, Z.; Krupnick, A. J. Shale gas development impacts on surface water quality in Pennsylvania. Proc. Natl. Acad. Sci. U. S. A. 2013, 110 (13), 49624967.

(13) Wilson, J. M. Wang Y. and VanBriesen, J. M., J. Environ. Eng. (Reston, VA, U.S.), DOI: 10.1061/(ASCE)EE.1943-7870.0000733 (May. 11, 2013).

(14) National Water Information System Database (http:// waterdata.usgs.gov/pa/nwis/uv?site_no=03042000) U.S. Geological Survey (accessed March 12, 2013).

(15) Moore, W. Radium isotope measurements using germanium detectors. Nucl. Instrum. Methods Phys. Res. 1984, 2-3, 407-411.

(16) Kim, G.; Burnett, W.; Dulaiova, H.; Swarzenski, P.; Moore, W. Measurement of 224Ra and 226Ra activities in natural waters using a radon-in-air monitor. Environ. Sci. Technol. 2001, 35 (23), 4680-4683.

(17) Vinson, D. S.; Lundy, J. R.; Dwyer, G. S.; Vengosh, A. Coupled use of $\mathrm{Sr}$ and $\mathrm{Ra}$ isotopes to assess Ra mobility and water-rock interaction in sandstone aquifers. Geochim. Cosmochim. Acta 2009, 73 (13), A1387-A1387.

(18) Chapman, E. C.; Capo, R. C.; Stewart, B. W.; Kirby, C. S.; Hammack, R. W.; Schroeder, K. T.; Edenborn, H. M. Geochemical and strontium isotope characterization of produced waters from Marcellus Shale natural gas extraction. Environ. Sci. Technol. 2012, 46 (6), 3545-3553.

(19) U.S. Environmental Protection Agency. Voluntary Sampling Data from Oil and Gas Wastewater Treatment Facilities. http://www. epa.gov/region3/marcellus_shale/\#epawpadep.

(20) Kendall, C.; Coplen, T. Distribution of oxygen-18 and deuterium in river waters across the United States. Hydrol. Processes 2001, 15, 1363-1393.

(21) Sharma, S.; Sack, A.; Adams, J. P.; Vesper, D. J.; Capo, R. C.; Hartsock, A.; Edenborn, H. M. Isotopic evidence of enhanced carbonate dissolution at a coal mine drainage site in Allegheny County, Pennsylvania, USA. Appl. Geochem. 2013, 29, 32-42.

(22) Chapman, E. C.; Capo, R. C.; Stewart, B. W.; Hedin, R. S.; Weaver, T. J.; Edenborn, H. M. Strontium isotope quantification of siderite, brine and acid mine drainage contributions to abandoned gas well discharges in the Appalachian Plateau. Appl. Geochem. 2013, 31, 109-118.

(23) An Investigation of Naturally Occurring Radioactive Materials (NORM) in Oil and Gas Wells in New York State; New York Department of Environmental Conservation: Albany, New York, 1999.
(24) Shahul Hameed, P.; Shaheed, K.; Somasundaram, S. S. N.; Iyengar, M. A. R. Radium-226 levels in the Cauvery river ecosystem, India. J. Biosci. (New Delhi, India) 1997, 22 (2 March), 225-231.

(25) Peterson, R. N.; Burnett, W. C.; Opsahl, S. P.; Santos, I. R.; Misra, S.; Froelich, P. N. Tracking suspended particle transport via radium isotopes (226Ra and 228Ra) through the ApalachicolaChattahoochee-Flint River system. J. Environ. Radioact. 2013, 116, $65-75$.

(26) Cleanup and Disposal Guidelines for Sites Contaminated with Radium-226; Michigan Department of Environmental Quality, Waste and Hazardous Materials Division, 2007

(27) Smith, K. an Overview of Naturally Occuring Radioactive Material (NORM) in the Petroleum Industry; Environmental Assessment and Information Sciences Division, Argonne National Laboratory, 1992.

(28) Naturally Occurring Radioactive Materials (NORM) in Produced Water and Oil-Field Equipment-An Issue for the Energy Industry, Fact Sheet 0142-99; U.S. Geological Survey, 1999.

(29) Krishnaswami, S.; Bhushan, R.; Baskaran, M. Radium isotopes and $222 \mathrm{Rn}$ in shallow brines, Kharaghoda (India). Chem. Geol. Isot.. Geosci. 1991, 87 (2), 125-136.

(30) Webster, I. T.; Hancock, G. J.; Murray, A. S. Modelling the effect of salinity on radium desorption from sediments. Geochim. Cosmochim. Acta 1995, 59 (12), 2469-2476.

(31) Sturchio, N. C.; Banner, J. L.; Binz, C. M.; Heraty, L. B.; Musgrove, M. Radium geochemistry of ground waters in Paleozoic carbonate aquifers, midcontinent, USA. Appl. Geochem. 2001, 16 (1), 109-122.

(32) Iyengar, M.; Nrayana Rao, K. Uptake of radium by marine animals, In The Environmental Behaviour of Radium; IAEA, 1990; Vol. 1.

(33) Jeffree, R. The environmental behaviour of radium. In Radium uptake by freshwater invertibrates; IAEA, 1990; Vol. 1.

(34) Justyn, J. and Havlik, B. Radium uptake by freshwater fish. In The Environmental Behaviour of Radium, IAEA, 1990; Vol. 1.

(35) Williams, A. Radium uptake by Freshwater Plants. In The Environmental Behaviour of Radium, IAEA, 1990; Vol. 1. 